\title{
Gene Structure of the Human Receptor Tyrosine Kinase RON and Mutation Analysis in Lung Cancer Samples
}

\author{
Debora Angeloni, ${ }^{1 *}$ Alla Danilkovitch-Miagkova, ${ }^{\prime}$ Sergey V. Ivanov, ${ }^{2}$ Richard Breathnach, ${ }^{3}$ Bruce E. Johnson, ${ }^{4}$ \\ Edward J. Leonard,' and Michael I. Lerman' \\ 'Laboratory of Immunobiology, National Cancer Institute, Frederick Cancer Research and Development Center, Frederick, Maryland \\ ${ }^{2}$ Intramural Research Support Program, Science Applications International Corporation, Frederick Cancer Research and Development \\ Center, Frederick, Maryland \\ ${ }^{3}$ Institut de Biologie, Nantes, France \\ ${ }^{4}$ Medicine Branch at the Navy, National Cancer Institute, National Institutes of Health, Bethesda, Maryland
}

The human RON gene (MSTIR) maps to 3p2I.3, a region frequently altered in lung cancer and other malignancies. It encodes a receptor tyrosine kinase (RTK) closely related to MET, whose mutations are associated with neoplasia. We investigated whether RON might be involved in the development or progression of lung cancer. We first determined the exon-intron structure of the gene by direct sequencing of RON cosmid DNA and PCR products containing intronic sequences, and then developed primers suitable for mutation analysis by the single-strand conformation polymorphism (SSCP) method. Twenty coding exons were characterized, all but the first one small (average size: I70 bp), a feature shared with other RTK genes. We performed SSCP analysis of RON in small and non-small cell lung cancer samples, upon detection of its expression in a sample of lung cancer cell lines. A mutation (T915C: L296P) was found in an adenocarcinoma specimen. Several single nucleotide polymorphisms were also found. The panel of intron-anchored primers developed in this work will be useful for mutation analysis of the RON gene in different types of human tumors.

\section{INTRODUCTION}

The human RON gene (MST1R, according to the official nomenclature, see http://www.ncbi.nlm.nih. gov/LocusLink/list.cgi) encodes a receptor tyrosine kinase (RTK) of 1400 amino acids that belongs to the MET gene family (Ronsin et al., 1993). It is synthesized as a single-chain precursor that undergoes proteolytic cleavage into two single polypeptide chains linked by disulfide bonds. The mature heterodimeric protein is composed of one $\alpha-(35 \mathrm{kD})$ and one $\beta$-chain $(150 \mathrm{kD})$. The $\alpha$-chain is located extracellularly, whereas the $\beta$-chain contains an extracellular portion, a one-pass transmembrane helix, and an intracellular portion that harbors the tyrosine kinase domain. The number and the location of the disulfide bonds are still unknown. RON and its ligand, macrophage stimulating protein (MSP), are involved in the development of epithelial tissues, bones, and neuroectodermal tissues, driving cellular proliferation (Wang et al., 1994; Gaudino et al., 1995; Quantin et al., 1995). The genes coding for RON and MSP both map at 3p21.3 (http://www.ncbi.nlm.nih.gov/ genemap/map.cgi?CHR=3, Human Genome Map 1998), a region frequently altered in lung, kidney, and other malignancies (Brauch et al., 1987; Zbar et al., 1987; Ronsin et al., 1993; Kok et al., 1997). The predicted amino acid sequences of $R O N$ and MET (c) 2000 Wiley-Liss, Inc.

have overall $33 \%$ identity, which increases to $64 \%$ in the kinase domain.

Missense mutations located in the tyrosine kinase domain of the MET gene have been identified in the constitutional DNA of affected members of families with hereditary papillary renal cell carcinoma and in a subset of sporadic renal cell carcinomas of the same histology (Schmidt et al.,1997, 1998; Zbar and Lerman, 1998). These are likely to be gain/change-of-function mutations that lead to constitutive activation of the MET protein and tumorigenesis in the renal tissue (Schmidt et al., 1997, 1998). Similar mutations occurring in other RTKs are associated with different human malignancies, namely, mastocytomas and gastrointestinal tumors in the case of KIT (Nagata et al., 1995; Piao and Bernstein, 1996; Hirota et al., 1998), multiple endocrine neoplasia types $2 \mathrm{~A}$ and $2 \mathrm{~B}$, and familial medullary thyroid carcinomas in the case of RET (Mulligan et al., 1993; Hofstra et al., 1994). Muta-

\footnotetext{
Supported by: National Cancer Institute, National Institutes of Health; Grant number: NO1-CO-56000.

*Correspondence to: Debora Angeloni, Laboratory of Immunobiology, National Cancer Institute, Frederick Cancer Research and Development Center, Frederick, MD 21702-1201.

E-mail: andreazzolid@mail.ncifcrf.gov

Received 3 November 1999; Accepted 30 March 2000
} 
tions (D1232V and M1254T) introduced into the RON kinase domain induce oncogenic and metastatic properties (Santoro et al., 1998). These mutant RON receptors show an increased kinase catalytic efficiency. Additional findings, both in vivo and in vitro, suggest that $R O N$ could be an oncogene. In liver progenitor cells, RON activation has a strong cell dissociation, motogenic and mitogenic activity (Medico et al., 1996). In a breast cancer cell line (ZR75.1), RON activation led to more rapid proliferation, migration, and invasion (Maggiora et al., 1998). Rearrangements occurring in the extracellular region of the protein result in altered kinase activity. For example, a $R O N$ splicing variant discovered in a gastric carcinoma cell line (KATOIII) was found to be responsible for invasive properties acquired in vitro by these cells (Collesi et al., 1996). The uncleaved single-chain RON protein undergoes aberrant intermolecular disulfide dimerization and intracellular oligomerization, and shows constitutive activation along with the potential of eliciting a motile-invasive phenotype. The effects on cell motility shown by the RON/MSP system were intriguing in view of the high metastatic activity of SCLC cells.

To investigate whether the putative proto-oncogene $R O N$ could contribute to the development or progression of lung cancer, we first showed that the gene is expressed in lung cancer cell lines. Next, we performed mutation analysis of the gene in 55 paired lung cancer samples (Johnson et al., 1988). $R O N$ cDNA was previously cloned (Ronsin et al., 1993), but the gene exon-intron structure was not elucidated. To perform a detailed mutation analysis of the $R O N$ gene in the lung cancer samples, it was necessary to define the exon-intron structure and develop intron-based primers suitable for exonic and splice-site sequence study. We solved the gene structure through a PCR/sequencing strategy, and designed intronic primers to apply the singlestrand conformation polymorphism (SSCP) method to do mutation analysis. We analyzed for mutations in the kinase-domain exons and the region containing the protein cleavage site in exon 1.

\section{MATERIALS AND METHODS}

\section{Northern Blot Analysis}

Filters carrying polyA + mRNA from several lung cancer cell lines were prepared according to Sambrook et al. (1989). Radioactive DNA probes were prepared by random priming (Rediprime II, Amersham, Arlington Heights, IL). Hybridization was performed in ExpressHyb hybridization solu- tion according to the manufacturer's instructions (Clontech Laboratories, Palo Alto, CA).

\section{Determination of the Exon-Intron Structure}

To define the exon-intron boundaries of RON, we designed several PCR primers on the cDNA sequence (GenBank accession number X70040). These primers were used on $R O N$ cosmid clones and $R O N$ cDNA. Comparing the PGR products by size allowed us to determine whether an intronic sequence was present. The sequencing of the PCR products to identify intronic sequence led to the characterization of the exon-intron boundaries. When this approach did not work, because of the presence of a large intron, we performed direct primer-walking sequencing on the cosmid DNA.

\section{PCR Reactions}

Each PCR primer pair (GIBCO-BRL, Gaithersburg, MD; BioServe Ltd, Laurel, MD) was tested by running the product on a $4 \% \quad 3: 1 \mathrm{Nu}$-Sieve agarose gel (FMC, Rockland, ME). All pairs were used under the following cycling conditions: $1 \mathrm{~min}$ at $95^{\circ} \mathrm{C}, 30 \mathrm{sec}$ at $64^{\circ} \mathrm{C}, 30 \mathrm{sec}$ at $72^{\circ} \mathrm{C}$, for 35 cycles. PCR products were cloned using a TA Cloning Kit (Invitrogen, Carlsbad, CA).

\section{Sequencing}

Sequencing reactions were done either manually (T7 Sequence Kit, Amersham, Arlington Heights, IL) or automatically (ABI 373 Stretch Automated DNA Sequencer, Applied Biosystems, Foster City, CA).

\section{Web-Based Sequence Analysis Servers}

The web-based sequence analysis servers used were: http://gnomic.stanford.edu/GENSCAN.html and http://www.sanger.ac.uk/Pfam/search.shtml.

\section{Single-Strand Conformation Polymorphism Analysis (SSCP)}

Each exon of the kinase domain, plus a region containing the proteolytic cleavage site in exon 1, was examined for mutation using a specific PCR primer pair (Table 1). The radioactive reaction was performed in a total reaction volume of $12.5 \mu \mathrm{l}$, containing $100 \mathrm{ng}$ of genomic DNA, $12.5 \mathrm{pmol}$ of each primer, $200 \mu \mathrm{M}$ dNTPs, $1.5 \mathrm{mM} \mathrm{MgCl} 2,1.25$ nCi $\alpha^{35} \mathrm{~S}$-dATP, and $0.5 \mathrm{U}$ AmpliTaq DNA polymerase (Perkin-Elmer). After heat denaturation (8 min at $90^{\circ} \mathrm{C}$ ) in formamide buffer (Stop Solution, Amersham, Arlington Heights, IL), PCR products (ranging in size from 88 to $298 \mathrm{bp}$ ) were run overnight in a $0.5 \times$ MDE gel (FMC Bioproducts, 
TABLE I. PCR Primers Used for SSCP Analysis of the RON Gene Kinase Domain-Coding Exons (exons 14-20) and Cleavage Site (exon I)

\begin{tabular}{|c|c|c|c|}
\hline PCR product & Size in bp & Forward primer & Reverse primer \\
\hline $876 \mathrm{~F}-97 \mathrm{IR}$ & 115 & 5'TTAGCGCCACTGAGCCAGAGTTGG & 5'AGCACAGGGTAGGGCTGTCC \\
\hline 92 IF-IOIIR & 112 & 5'TCGACTGCAGATTTGCTCCA & 5'GTGGCAAGTTGGGCACCCACTG \\
\hline EXON 14 & 159 & 5'GCGGAAAGAGTCCATCCAG & 5'CTTGAGACTCCATCTCTGC \\
\hline EXON I5 & 113 & 5'ATTATGCACCTCACACCAGGCCAC & 5'CTGCCCCACTTACGACTTAGTGAC \\
\hline EXON 16 & 206 & 5'TCGCTCTGCAGGCATCACAGAGATG & 5'GATGAACACTGACCCGCTGAGGTGA \\
\hline EXON 17 & 162 & 5'TTGCCCACCAACCCACCTGTG & 5'CACCCCAGCTACTCTGGACTC \\
\hline EXON 18 & 223 & 5'AGTCCTAAGTGTGATCCTCTCCСTAC & 5'GCCTCACCACATCAGACTTGGTGGT \\
\hline EXON 19 & 163 & 5'CCACAGTGGTCATTTGGTGTGCTGC & 5'CCACСТCCACATACTCACAGAGAATCAG \\
\hline EXON 20 & 108 & 5'CAGGTACCAAGTGATGCAGCAATGCTG & 5'TCCCCAAGCAGTGCAGACACTATCTG \\
\hline
\end{tabular}

Rockland, ME), 0.6× TBE, at room temperature, 8 $\mathrm{W}$ constant power, transferred to $3 \mathrm{MM}$ paper, dried, and exposed for autoradiography on film (X-OMAT AR, Kodak, Rochester, NY).

\section{Patient DNA and Cell Lines}

Fifty-five normal/tumor paired samples were analyzed, including thirty-four small cell lung carcinomas (SCLCs) and twenty-one non-small cell lung carcinomas (N-SCLCs). Tumor and lymphoblastoid cell lines were established from patients with lung cancer according to techniques previously described (Phelps et al., 1996). Tumor and normal tissue were obtained from patients at surgical resection or post-mortem examination (Johnson et al., 1988). The following DNA samples from CEPH individuals were used as negative controls: 1334-01, 1334-02, 66-01, 66-02, 45-01, 45-02, 133101, 1331-02, 1345-01, 1345-02, 28-01, 28-02, 21-01, 21-02, 1347-01, 1347-02, 1332-12, 1332-13, 1349-01, 1349-02, 1350-10, 1350-11, 1421-10, 1421-11, 1416$10,1416-11,1346-01,1346-02,1400-01,1400-02$, 104-01, 104-02, 1355-01, 1355-02, 1427-01, 1427-02, $12-10,12-11,17-01,17-02,884-01,884-02,1420-10$, 1420-11.

\section{RON Cosmids}

$R O N$ cosmid clones (designated numbers 5, 6, 11 , 12,19 , and 20) were isolated by screening of a human fetal brain genomic library in the SuperCos 1 vector using the $R O N$ cDNA as a probe under conditions specified by the vendor (Stratagene, La Jolla, CA). The average insert size of these clones was estimated to be between 35 and $45 \mathrm{~kb}$.

\section{Site-Directed Mutagenesis}

T915C base change was introduced into $R O N$ cDNA using the GeneEditor In Vitro Site-directed Mutagenesis System (Promega, Madison, WI), according to the manufacturer's instructions. The mutagenesis primer sequence was 5' P-CTA TCG GGA GCC GGT CCT CG (GIBCO-BRL, Gaithersburg, MD).

\section{Cell Lines and Culture Conditions}

MDCK cells (ATCC, Manassas, VA) were stably transfected with wild-type or L296P RON cDNA in pCl-neo vector (Promega, Madison, WI) or with empty pCI-neo vector (MOCK) by superfect reagent (Quiagen, Santa Clara, CA), and placed in medium with $500 \mu \mathrm{g} / \mathrm{ml}$ geneticin (GIBCO-BRL, Gaithersburg, MD). After two weeks, the geneticin-resistant cells were picked up and expanded into cell lines. Expression of recombinant RON was tested by Western blotting with anti-RON antibodies (Santa Cruz Biotechnology, Santa Cruz, CA). Transfected MDCK cell lines were cultured in DMEM (GIBCO-BRL) with 10\% FCS (HyClone Lab, Logan, U'T).

\section{Cell Stimulation, Lysis, and Western Blotting}

After overnight starvation in DMEM without FCS, cells were collected from dishes and stimulated in suspension with $5 \mathrm{nM}$ MSP (Toyobo, Osaka, Japan) for $15 \mathrm{~min}$. After stimulation, cells were lysed in lysis buffer (50 mM HEPES, pH 7.4, $150 \mathrm{mM} \mathrm{NaCl}, 10 \%$ glycerol, $1 \mathrm{mM}$ EDTA, $1 \mathrm{mM}$ sodium orthovanadate, $10 \mathrm{mM}$ sodium pyrophosphate, $100 \mathrm{mM} \mathrm{NaF}, 1 \%$ Triton X-100, $10 \mu \mathrm{g} / \mathrm{ml}$ leupeptin, $10 \mathrm{U} / \mathrm{ml}$ aprotinin, $1 \mathrm{mM}$ PMSF). Insoluble material was removed by centrifugation. RON receptor was immunoprecipitated from supernatants using rabbit polyclonal antibodies designed on the RON receptor C-terminus (Santa Cruz Biotechnology). RON tyrosine phosphorylation was detected by Western blotting using anti-phosphotyrosine antibodies (anti-PY, clone 4G10, UBI, Lake Placid, NY). Rabbit anti-RON antibodies were used for detection of $\mathrm{RON}$ receptor on the membranes. 

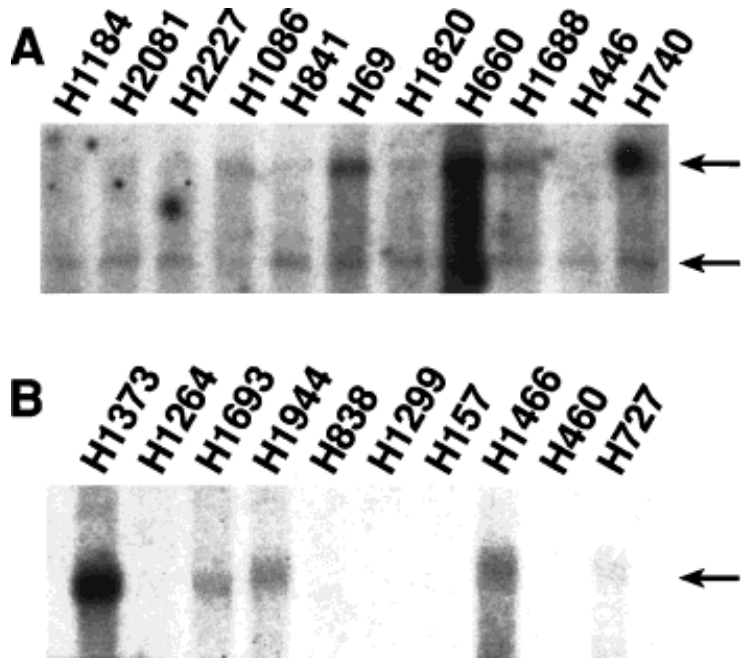

Figure I. Northern blot analysis. RON complete cDNA was used as probe in Northern blot experiments. (A) poly-A + mRNA from smallcell lung cancer cell lines. (B) poly-A+ mRNA from non-small cell lung cancer cell lines. The arrow in $B$ and the upper arrow in $A$ point to a $4.5 \mathrm{~kb}$ transcript. A smaller transcript was found in small-cell lung cancer cell lines ( $2 \mathrm{~kb}$, lower arrow in blot $A)$.

\section{RESULTS}

RON Gene is Not Homozygously Deleted in Lung Cancer Cell Lines

To investigate the retention of $R O N$ in the DNA of lung cancer cell lines known to have homozygous deletions in 3p21.3 (Wei et al., 1996), we performed PCR with primers for exon 16 (Table 1). We analyzed the lung cancer cell lines GLC 20, NCI-H740, and NCI-H1450 that harbor the deletions (Wei et al., 1996). The gene is not deleted in any of the three tested cell lines (data not shown).

\section{Expression Study in Lung Cancer Cell Lines}

$R O N$ cDNA was used as a probe in Northern blotting experiments. A panel of small and nonsmall lung cancer cell lines showed high to moderate expression of the $4.5 \mathrm{~kb}$ species in the majority of samples (Fig. 1A upper arrow; 1B). In addition, a signal of approximately $2 \mathrm{~kb}$ was detected in small, but not in non-small cell lines (Fig. 1A, lower arrow).

\section{Characterization of the Exon-Intron Structure}

Several PCR primer pairs were designed to cover the whole $R O N$ cDNA sequence (GenBank accession number X70040). Comparison of PCR products generated from genomic DNA and RON cDNA allowed detection of the position of intronic sequences. In the case of large introns, we performed direct primer-walking sequencing using cosmid DNA. We identified a total of twenty exons (Fig. 2). The first exon is also the largest, spanning 1229 bp. The last exon extends from nucleotide 3976 to 4532 , where the polyA tail is inserted. Our results confirm the existence of two previously reported exons at bases 2678 and 2825 (Collesi et al., 1996). With the exception of the first one, the coding exons are small, ranging in size from $93 \mathrm{bp}$ to 253 bp (Table 2). The first, 14th, and 19th introns were not completely sequenced. Intron 19 was estimated to be about $2.5 \mathrm{~kb}$ in size. The whole gene cannot span more than about $35-45 \mathrm{~kb}$, because it is contained in a single cosmid clone (data not shown). The intronic sequences were deposited with the GenBank (accession numbers: AF164633, AF164634, AF164635, AF164636, AF164637, AF164638, AF164639, AF164640, AF164641, AF164642, AF164643, AF164644, AF164645, AF164646, AF164647, AF164648, AF164649, AF164650, AF164651, AF164652, AF164653, AF164654).

By using the GENSCAN gene prediction program (Burge and Karlin, 1997; http://gnomic.stanford.edu/ GENSCAN.html), we checked whether any alternative splicing could be detected. We found that exon 10 could begin with a CAG triplet (coding for a Gln residue) upstream of the canonical TGT (coding for the canonical Cys) without modifying the consensus splicing site sequence $5^{\prime}$...nCAG3'. Another interesting possibility was found at residue 1091, where, after the canonical VIGKG sequence, the theoretical alternative splicing inserts a stretch of bases encoding 6 more amino acids (namely, VGARPG). This last possibility occurs at the very beginning of the kinase domain. A PCR experiment was performed with cDNAs from human fetal and adult lung (Clontech, Palo Alto, CA) to search for the predicted alternatively spliced forms of $R O N$. This experiment gave negative results (data not shown). It is worth mentioning, however, that inactivating mutations responsible for disease states caused by the Wilms' tumor suppressor gene (WT1) occur in amino acid residues subjected to alternative splicing (Hewitt et al., 1996).

\section{Mutation Analysis}

With a panel of primers (Table 1), we performed SSCP analysis of a stretch of bases in exon 1, encoding the putative cleavage site (KRRRR) in the RON protein, to verify whether any mutation at this site could interfere with correct maturation of the protein. We also analyzed exons 14, 15, 16, $17,18,19$, and part of 20 , that encode the tyrosine 


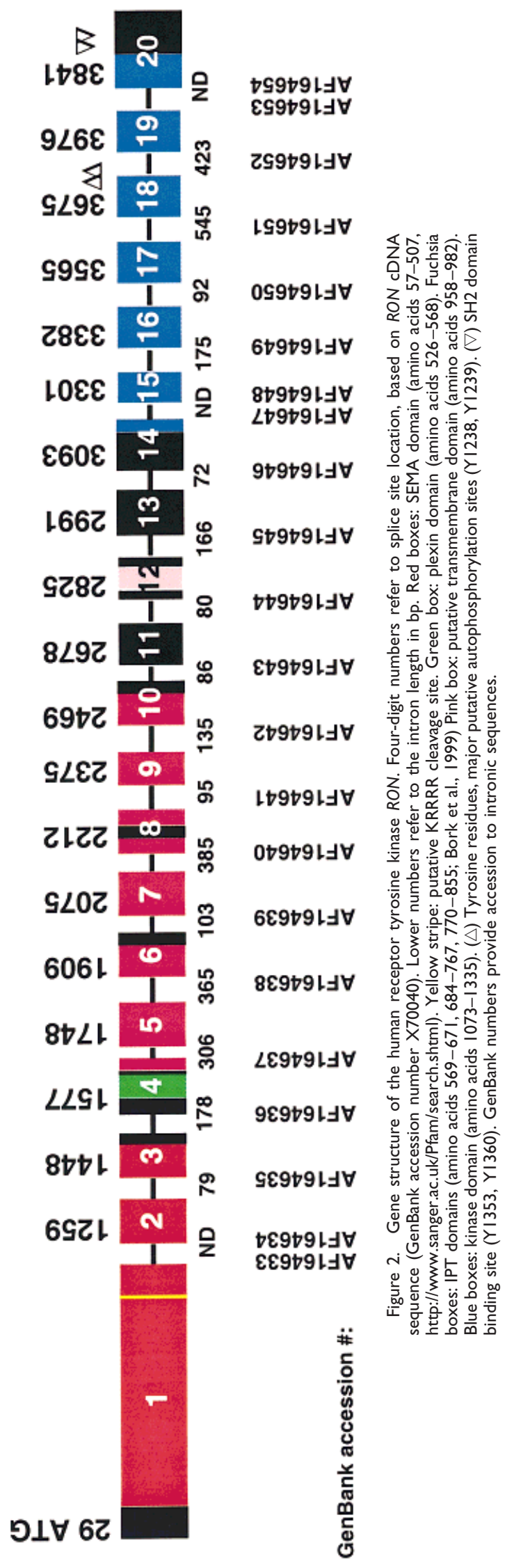

kinase domain (PFAM: Bateman et al., 1999; http:// www.sanger.ac.uk/Pfam/search.shtml).

A T-to-C transition was found at base 915 (tat cgg gag ct/cg gtc ctc) in the tumor DNA of an adenocarcinoma patient (Patient 122-208). This base change causes an L-to-P change at residue 296 (Fig. 3A) and is present neither in the blood-derived DNA of the patient (Fig. 3A) nor in 44 control individuals (CEPH individuals' DNA; Dausset et al., 1990). The mutation eliminates an AluI site and allows the formation of a Cfr $10 \mathrm{I}$ restriction site, which cuts the PCR product amplified by primers $876 \mathrm{~F}-917 \mathrm{R}$ ('Table 1) in two fragments of 38 and 77 bp. A change was found at base 993: an A-to-G transition leads to a Q322R amino-acid change (Fig. 3B). This is a single nucleotide polymorphism (SNP), already observed by Collesi et al., (1996). It is present in the normal population with an index of heterozygosity of $0.28(P=0.17, \mathrm{q}=0.83)$. This SNP cancels a $B s p \mathrm{MI}$ restriction site in the PCR product of primers $921 \mathrm{~F}-1011 \mathrm{R}$ (Table 1), otherwise cut into two fragments of 31 and $71 \mathrm{bp}$. In exon 20, two SNPs were found (Fig. 3C, 3D): a C-to-T transition of base 4024 (gtg cga ccc/t acc ttc aga; same-sense variant $\mathrm{P} 1341 \mathrm{P})$ and an A-to-G transition of base 4031 (ccc acc ttc a/gga gta: R1344G). Both SNPs were found in CEPH individuals' DNA (Dausset et al., 1990), with indices of heterozygosity, respectively, of 0.03 and 0.46 . These SNPs do not produce any change in the restriction map.

\section{Protein Analysis}

Because the T915C mutation was found only in a tumor sample, we investigated the kinase activity of the L296P RON mutant. To compare the mutant protein with wild-type RON, we introduced the $T 915 \mathrm{C}$ base change into $R O N \mathrm{cDNA}$, through a site-specific mutagenesis procedure. MDCK cells stably transfected with C915 T-mutagenized $R O N$ cDNA express RON protein that shows the same electrophoretic profile as the wild-type protein (Fig. 4A). Therefore, the mutation, although close to the cleavage site, does not block the precursor cleavage and protein maturation. The mutated protein is responsive to MSP, and the kinase activity, elicited upon MSP stimulation, is equivalent to the wild-type activity (Fig. 4B).

\section{DISCUSSION}

We established the exon/intron structure of the human $R O N$ gene. The coding sequence is represented by twenty exons. Ranging in size from 93$253 \mathrm{bp}$, they all are quite small, a feature shared 
TABLE 2. Data on Exons and Introns of the Human RON Gene

\begin{tabular}{|c|c|c|c|c|c|c|}
\hline $\begin{array}{l}\text { Exon no. } \\
\text { (length in bp) }\end{array}$ & Ends $^{\mathrm{a}}$ & $\begin{array}{c}\text { Intron } \\
\text { no. }\end{array}$ & Type $^{\text {b }}$ & Intron $5^{\prime}$ end ${ }^{c}$ & $\begin{array}{l}\text { Length } \\
\text { in bp }\end{array}$ & Intron $3^{\prime}$ end ${ }^{c}$ \\
\hline I (I229) & ATG 29-1258 & I & 0 & CCCAACCCG(I258)/gtaagctga & ND & ctttcccag/(I259)CCTGGCCTG \\
\hline $2(188)$ & $1259-\mid 447$ & 2 & 0 & TATCCTGCAG/gtgggtcctc & 79 & cctgtcctag/GTGGAGCTGG \\
\hline $3(128)$ & |448-|576 & 3 & 0 & TGGGGACCAG/gtgaggtggg & 178 & tcacccacag/GTTTTCCAGG \\
\hline $4(170)$ & |577-|747 & 4 & 0 & GCTTACTGAG/gtatggcttc & 306 & cccatttcag/TTCCACCCCC \\
\hline $5(160)$ & $1748-1908$ & 5 & II & CAAAACTCAG/gtacaatctg & 365 & tggtgccccag/ACCAGTGCCC \\
\hline $6(165)$ & 1909-2074 & 6 & 0 & CTCTTTCATG/gtgaggctac & 103 & gtcctcttag/GAGCCAGTGC \\
\hline 7 (136) & $2075-2211$ & 7 & II & TGCTAGCACG/gtaagtacca & 385 & gttcctgtag/GGTCAGTGAG \\
\hline $8(162)$ & $2212-2374$ & 8 & II & GTGGCTACAT/gtaagcactg & 95 & tcttccacag/CAACTCCCAC \\
\hline $9(93)$ & $2375-2468$ & 9 & 0 & GGAAAGCAGG/gtgagtgagt & 135 & gtcccagcag/TGTGAGAGGC \\
\hline $10(208)$ & $2469-2677$ & 10 & 0 & TAAGTTTGAG/gtaagtgtaa & 86 & ctctctgcag/TATATTGGGC \\
\hline II (146) & $2678-2824$ & 11 & 0 & CCCATTGCAG/gtaggcagcc & 80 & ctgcccccag/GTCTGCGTAG \\
\hline $12(165)$ & $2825-2990$ & 12 & I & AAGCAGCTAG/gtgagttctc & 166 & ctttccacag/TTCTТССТСС \\
\hline $13(101)$ & $299 \mid-3092$ & 13 & I & AGTGGCCTTG/gtgagatagt & 72 & ttccccacag/CACTCССТGC \\
\hline $14(207)$ & $3093-3300$ & 14 & I & ATTGGCAAAG/gtgtgggggc & ND & ctcagaccag/GCCACTTTGG \\
\hline $15(80)$ & $330 I-338 I$ & 15 & I & TCACTAAGTC/gtaagtgggg & 175 & cgctctgcag/GCATCACAGA \\
\hline $16(182)$ & $3382-3564$ & 16 & 0 & ACCTCAGCGG/gtcagtgttc & 92 & gtgcccccag/AACCCCACCG \\
\hline $17(109)$ & $3565-3674$ & 17 & II & GGAACTGCAT/gtgagagtcc & 545 & tacccctaag/GCTGGACGAG \\
\hline $18(165)$ & $3675-3840$ & 18 & 0 & GTCTGATGTG/gtgaggcccc & 423 & ctttccacag/TGGTCATTTG \\
\hline $19(136)$ & $384 I-3977$ & 19 & II & CTGATTCTCT/gtgagtatgt & ND & cccccaacag/GTACCAAGTG \\
\hline $20(556)$ & $3978-4534$ & & & & & \\
\hline
\end{tabular}

${ }^{a}$ Four-digit numbers refer to RON cDNA sequence (GenBank acc. No. X70040).

${ }^{\mathrm{b}}$ As classified in Sharp (198I).

${ }^{\mathrm{C}}$ Capital letters represent exonic sequence.

with other receptor tyrosine kinases (Andre et al., 1992; Kwok et al., 1993; Duh et al., 1997). All intronic splice junction sites show the consensus sequence 5' GT (x)n AG 3' (Mount, 1982). Excluding the three largest ones, the intronic sequences have an average size of $205 \mathrm{bp}$, ranging from 79$545 \mathrm{bp}$ in length.

There is quite a remarkable conservation of the exon-intron organization of the human $R O N$ gene and its mouse ortholog, Stk (Waltz et al., 1998). The intervening sequences are of the same type (as classified by Sharp, 1981) and in the same place, with the exception of the human exon 13, which, along with the adjacent intron 13 , is not present in the mouse gene. Similarly to the mouse Stk gene (Waltz et al., 1998), the first exon is the largest and codes for the putative proteolytic cleavage site KRRRR. The PFAM (http://www.sanger.ac.uk/ Pfam/search.shtml) protein domains alignment program detected a SEMA domain, located in the first, second, and third exons of the RON gene (corresponding to amino acid residues 58-507). The SEMA domain consists of a highly conserved stretch of about 500 amino acids (Kolodkin et al., 1993), initially identified in the Semaphorin family of proteins. It is characterized by fifteen conserved cysteines, one conserved potential $\mathrm{N}$-linked glycosylation site, and several blocks of conserved residues throughout the domain (Kolodkin et al.,
1993). Besides the RON and MET receptor tyrosine kinases (human and orthologs), PFAM retrieves the SEMA domain in Semaphorins, Neuropilins, and the orphan receptors of the SEX family (Maestrini et al., 1996), expressed in neural and epithelial cells. Unlike the RON/MET family, the SEX family proteins do not have any kinase activity.

Although the role of the SEMA domain is not clarified, it was shown that it could function in homophilic binding in the presence of calcium ions (Ohta et al., 1995). We propose that, owing to its location in RON and MET, the SEMA domain could be involved in ligand binding and receptor homodimerization upon ligand stimulation. Studies are ongoing to investigate the functional role of the SEMA domain in RON. Other structural features are located as follows (Fig. 2): a plexin domain (http://www.sanger.ac.uk/Pfam/search.shtml) in exon 4; three IPT domains (Bork et al., 1999)

Figure 3. Mutation analysis. The SSCP profile of each base change is shown, along with the sequence. A dot marks the mutated base. (A) T915C: L296P mutation. T: DNA from a lung adenocarcinoma sample. The arrow points to the mutated base found in this sample. The mutation affects the SEMA domain. N: blood-derived DNA from the same patient. (B) A993G; Q322R SNP. This polymorphism occurs in the SEMA domain. SNPs occurring in exon 20: (C) C4024T:PI 34IP, (D) A403IG:RI344G 
A

B

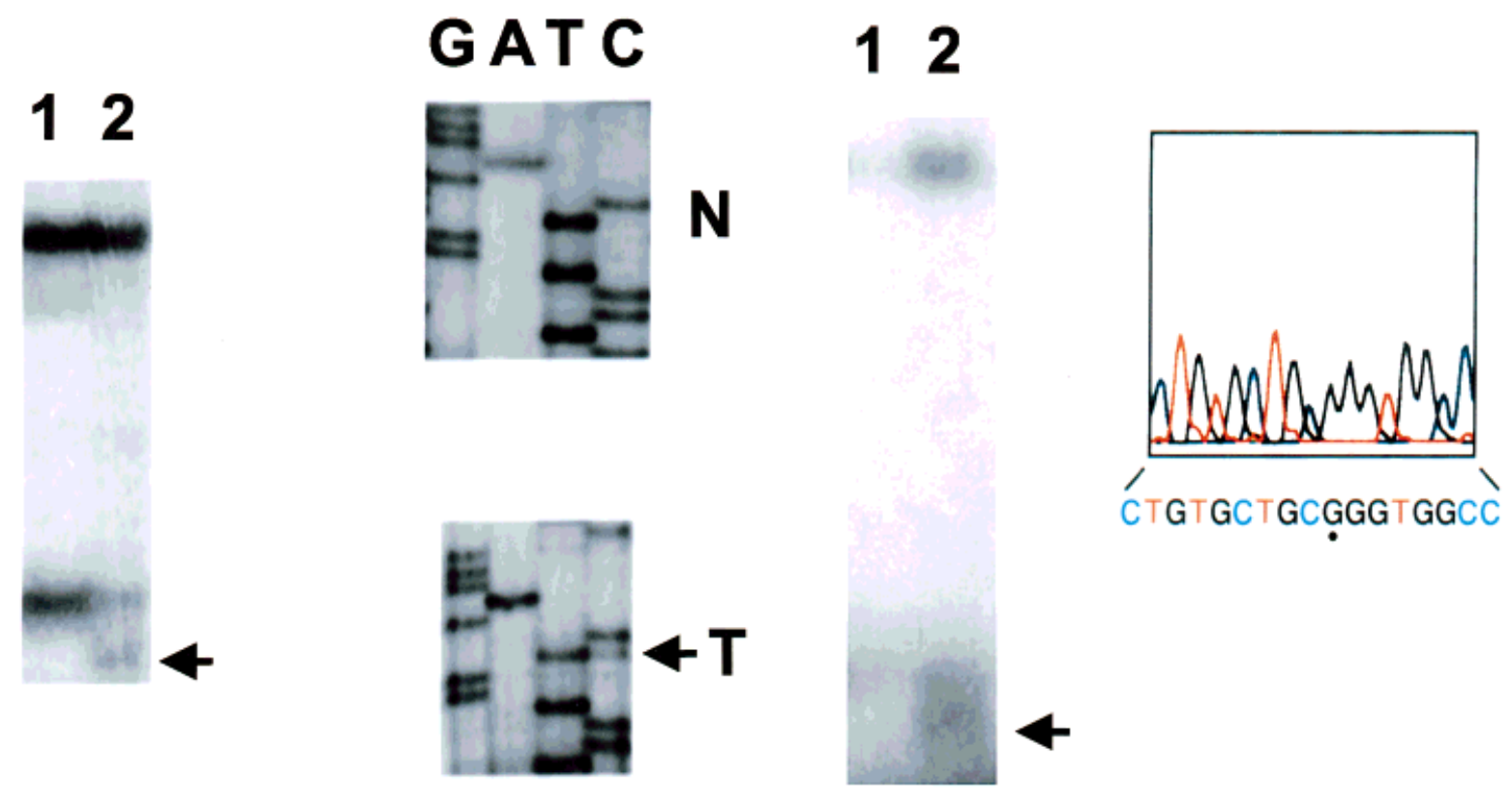

C

D
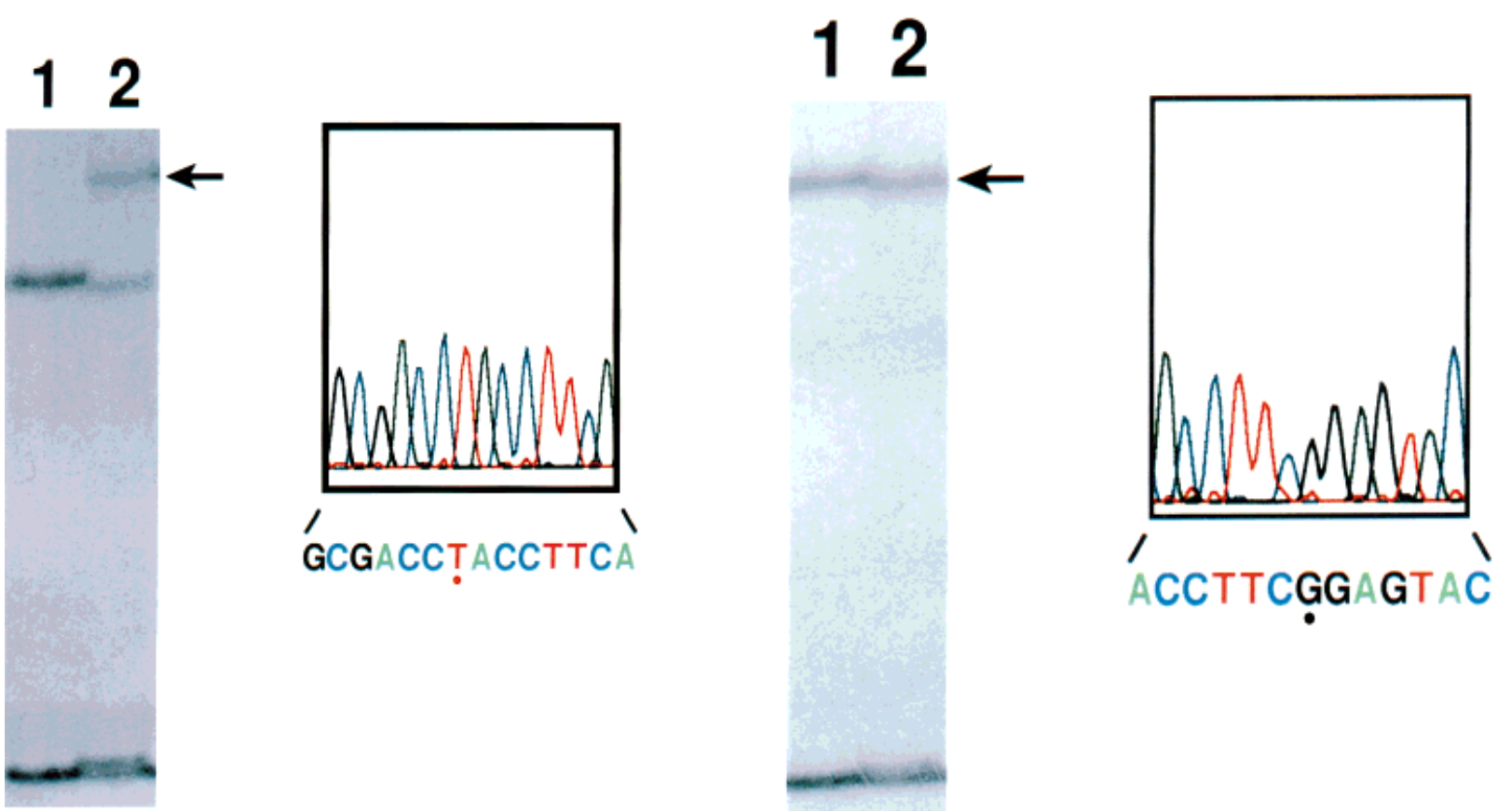


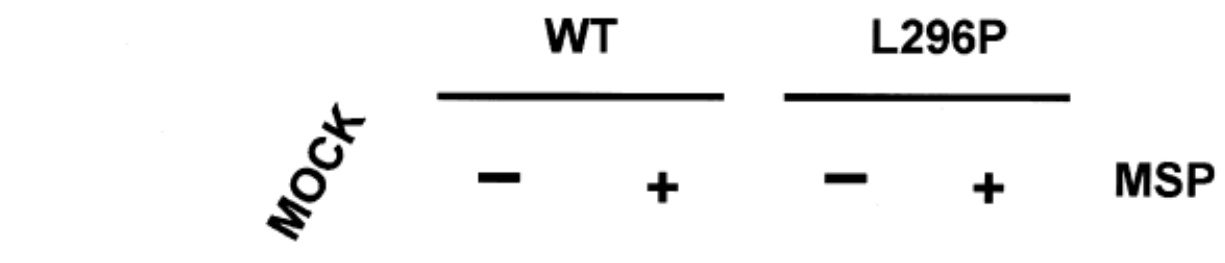

IP:Ron WB:Ron

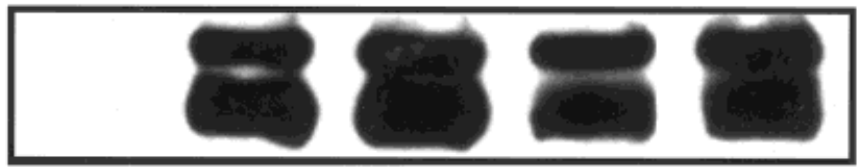

A

IP:Ron WB:PY

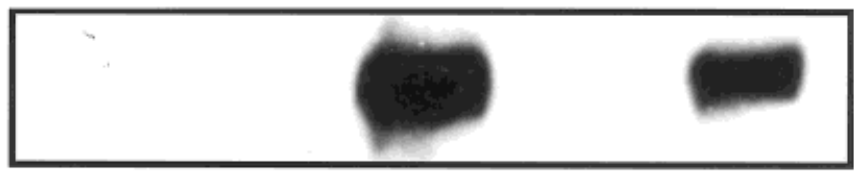

B

Figure 4. Analysis of the mutant RON protein. MDCK cells stably expressing wild-type RON (WT) or L296P mutant were stimulated with MSP (see Materials and Methods), and then lysed. RON was immunoprecipitated from cell lysates. Parental MDCK cells transfected with empty vector (MOCK) were used as a negative control. (A)

distributed in exons 4-10; a putative transmembrane domain in exon 12; the tyrosine kinase domain in exons 14-20; two conserved, adjacent tyrosine residues, that should serve as putative major autophosphorylation sites in exon 18; and the $\mathrm{SH} 2$ binding site (Ponzetto et al., 1994; Zhen et al., 1994) in exon 20.

The hypothesis of RON involvement in lung cancer was tested by mutation analysis of the kinase domain (exons 14-20), because evidence exists that oncogenic mutations found in the MET kinase domain, when introduced into $\mathrm{RON}$, are able to activate its oncogenic potential (Santoro et al., 1998). We also analyzed the region containing the cleavage site in exon 1 , to check for mutation that could possibly interfere with the cleavage/ maturation process. Using the SSCP protocol followed by sequencing, we identified a C-to-T transition at base 915 (leading to L296P mutation) in the tumor DNA of an adenocarcinoma patient. Leu296 is conserved among human, mouse, and Xenopus $R O N$ orthologues. It is substituted by Ile, a very similar amino acid, in the chicken homologue, c-SEA. Despite this conservation, however, the mutated amino acid does not seem to play a fundamental role, because the substitution L296P does not change the protein cleavage and maturation (as deduced by the electrophoretic profile) and the ligand-induced phosphorylation status, and therefore, most likely, the overall protein function.
Immature (upper band) and mature (lower band) forms of RON. This blot, developed with anti-RON antibodies, serves also as a control for the amount of RON in precipitates. (B) RON tyrosine phosphorylation was detected by Western blotting with anti-phosphotyrosine (PY) antibodies.

Thus, from our mutation analysis in lung cancer samples, we can rule out the possibility that RON plays a causative role in lung cancer initiation, at least with a mechanism involving mutations of the kinase domain or the cleavage site in exon 1. Several polymorphisms were found: A993G:Q322R (confirming the observation of Collesi et al., 1996); C4024T:same-sense variant; and A4031G:R1344G.

While this manuscript was in preparation, Persons et al. (1999) reported that the FV2 locus, which confers susceptibility to the Friend erythroleukemia virus in mice, encodes a truncated form of Stk, the mouse ortholog of RON (Waltz et al., 1998). Noticeably, the Northern analysis of smallcell lung cancer cell lines (Fig. 1A) showed a smaller (about $2 \mathrm{~kb}$ ) transcript of $R O N$, present in all samples, whereas the normal-size transcript was absent in some. This circa $2 \mathrm{~kb}$ transcript was not present at all in the non-small cell lines (Fig. 1 B), that expressed only the normal $(4.5 \mathrm{~kb})$ transcript. We are in the process of studying the nature and possible role of this smaller transcript in small cell lung cancer. In fact, a transcript approximately $2 \mathrm{~kb}$ in size was reported by others in some normal tissues (Ronsin et al., 1993; Gaudino et al., 1994), but the nature, function, and possible significance of this molecule in human physiology and pathology remain unknown at present.

In conclusion, further research is required to discover human tumors in which $R O N$ mutations 
may play a causative role. The panel of primers developed in this study is a useful tool for further mutation analyses in human malignancies.

\section{ACKNOWLEDGMENTS}

The authors thank Dr. Alexei Miagkov for his help in preparing illustrations and Dr. Massimiliano Andreazzoli for critical reading of the manuscript. The content of the publication does not necessarily reflect the views or policies of the Department of Health and Human Services, nor does mention of trade names, commercial products, or organizations imply endorsement by the U.S. Government.

\section{REFERENCES}

Andre C, Martin E, Cornu F, Hu WX, Wang XP, Galibert F. 1992. Genomic organization of the human c-kit gene: evolution of the receptor tyrosine kinase subclass III. Oncogene 7:685-691.

Bateman A, Birney E, Durbin R, Eddy SR, Finn RD, Sonnhammer ELL 1999. Pfam 3.1: 1313 multiple alignments and profile HMMs match the majority of proteins. Nucleic Acids Res 27:260-262.

Bork P, Doerks T, Springer TA, Snel B. 1999. Domains in plexins: links to integrins and transcription factors. Trends Biochem Sci 24:261-263.

Brauch H, Johnson B, Hovis J, Yano T, Gazdar A, Pettengill OS, Graziano S, Sorenson GD, Poiesz BJ, Minna J, et al. 1987. Molecular analysis of the short arm of chromosome 3 in small-cell and non-small-cell carcinoma of the lung. N Engl J Med 317:11091113.

Burge C, Karlin S. 1997. Prediction of complete gene structures in human genomic DNA. J Mol Biol 268:78-94.

Collesi C, Santoro MM, Gaudino G, Comoglio PM. 1996. A splicing variant of the $R O N$ transcript induces constitutive tyrosine kinase activity and an invasive phenotype. Mol Cell Biol 16:5518-5526.

Dausset J, Cann H, Cohen D, Lathrop M, Lalouel JM, White R. 1990. Centre d'étude du polymorphisme humain (CEPH): collaborative genetic mapping of the human genome. Genomics 6:575577.

Duh FM, Scherer SW, Tsui LC, Lerman MI, Zbar B, Schmidt L. 1997. Gene structure of the human MET proto-oncogene. Oncogene 15:1583-1586.

Gaudino G, Avantaggiato V, Follenzi A, Acampora D, Simeone A, Comoglio PM. 1995. The proto-oncogene $R O N$ is involved in development of epithelial, bone and neuro-endocrine tissues. Oncogene 11:2627-2637.

Hewitt SM, Fraizer GC, Wu YJ, Rauscher 3rd FJ, Saunders GF. 1996. Differential function of Wilms tumor gene WT1 splice isoforms in transcriptional regulation. J Biol Chem 271:85888592.

Hirota S, Isozaki K, Moriyama Y, Hashimoto K, Nishida T, Ishiguro S, Kawano K, Hanada M, Kurata A, Takeda M, Muhammad Tunio G, Matsuzawa Y, Kanakura Y, Shinomura Y, Kitamura Y. 1998. Gain-of-function mutations of c-kit in human gastrointestinal stromal tumors. Science 279:577-580.

Hofstra RM, Landsvater RM, Ceccherini I, Stulp RP, Stelwagen T, Luo Y, Pasini B, Hoppener JW, van Amstel HK, Romeo G, et al 1994. A mutation in the RET proto-oncogene associated with multiple endocrine neoplasia type $2 \mathrm{~B}$ and sporadic medullary thyroid carcinoma. Nature 367:375-376.

Johnson BE, Makuch RW, Simmons AD, Gazdar AF, Burch D, Cashell AW. 1988. myc family DNA amplification in small cell lung cancer patients' tumors and corresponding cell lines. Cancer Res 48:5163-5166.

Kok K, Naylor SL, Buys CH. 1997. Deletions of the short arm of chromosome 3 in solid tumors and the search for suppressor genes. Adv Cancer Res 71:27-92.

Kolodkin AL, Matthes DJ, Goodman CS. 1993. The semaphorin genes encode a family of transmembrane and secreted growth cone guidance molecules. Cell 75:1389-1399.

Kwok JB, Gardner E, Warner JP, Ponder BA, Mulligan LM. 1993.
Structural analysis of the human ret proto-oncogene using exon trapping. Oncogene 8:2575-2582.

Maestrini E, Tamagnone L, Longati P, Cremona O, Gulisano M, Bione S, Tamanini F, Neel BG, Toniolo D, Comoglio PM. 1996. A family of transmembrane proteins with homology to the METhepatocyte growth factor receptor. Proc Natl Acad Sci USA 23: 674-678.

Maggiora P, Marchio S, Stella MC, Giai M, Belfiore A, De Bortoli M, Di Renzo MF, Costantino A, Sismondi P, Comoglio PM. 1998. Overexpression of the $R O N$ gene in human breast carcinoma. Oncogene 16:2927-2933.

Medico E, Mongiovi AM, Huff J, Jelinek MA, Follenzi A, Gaudino G, Parsons JT, Comoglio PM. 1996. The tyrosine kinase receptors RON and SEA control "scattering" and morphogenesis of liver progenitor cells in vitro. Mol Biol Cell 7:495-504.

Mount S. 1982. A catalogue of splice junction sequences. Nucleic Acids Res 10:459-472.

Mulligan LM, Kwok JB, Healey CS, Elsdon MJ, Eng C, Gardner E, Love DR, Mole SE, Moore JK, Papi L, et al. 1993. Germ-line mutations of the RET proto-oncogene in multiple endocrine neoplasia type 2A. Nature 363:458-460.

Nagata H, Worobec AS, Oh CK, Chowdhury BA, Tannenbaum S, Suzuki Y, Metcalfe DD. 1995. Identification of a point mutation in the catalytic domain of the proto-oncogene c-kit in peripheral blood mononuclear cells of patients who have mastocytosis with an associated hematological disorder. Proc Natl Acad Sci USA 92:10560-10564

Ohta K, Mizutani A, Kawakami A, Murakami Y, Kasuya Y, Takagi S, Tanaka H, Fujisawa H. 1995. Plexin: a novel neuronal cell surface molecule that mediates cell adhesion via a homophilic binding mechanism in the presence of calcium ions. Neuron 14:11891199.

Persons DA, Paulson RF, Loyd MR, Herley MT, Bodner SM, Bernstein A, Correll PH, Ney PA. 1999. Fv2 encodes a truncated form of the Stk receptor tyrosine kinase. Nat Genet 23:159165.

Phelps RM, Johnson BE, Ihde DC, Gazdar AF, Carbone DP, McClintock PR, Linnoila RI, Matthews MJ, Bunn PA Jr, Carney D, Minna JD, Mulshine JL. 1996. NCI-Navy Medical Oncology Branch cell line data base. J Cell Biochem 24(Suppl):32-91.

Piao X, Bernstein A. 1996. A point mutation in the catalytic domain of c-kit induces growth factor independence, tumorigenicity, and differentiation of mast cells. Blood 87:3117-3123.

Ponzetto C, Bardelli A, Zhen Z, Maina F, dalla Zonca P, Giordano S, Graziani A, Panayotou G, Comoglio PM. 1994. A multifunctional docking site mediates signaling and transformation by the hepatocyte growth factor/scatter factor receptor family. Cell 77: 261-271.

Quantin B, Schuhbaur MC, Gesnel P, Dolle' P, Breatnach R. 1995. Restricted expression of the $R O N$ gene encoding the macrophage stimulating protein receptor during mouse development. Dev Dynamics 204:383-390.

Ronsin C, Muscatelli F, Mattei MG, Breathnach R. 1993. A novel putative receptor protein tyrosine kinase of the MET family. Oncogene 8:1195-1202.

Sambrook J, Fritsch EF, Maniatis T. 1989. Molecular cloning. A laboratory manual, 2nd edition. Cold Spring Harbor: Cold Spring Harbor Laboratory Press.

Santoro MM, Penengo L, Minetto M, Orecchia S, Cilli M, Gaudino G. 1998. Point mutations in the tyrosine kinase domain release the oncogenic and metastatic potential of the RON receptor. Oncogene 17:741-749.

Schmidt L, Duh FM, Chen F, Kishida T, Glenn G, Choyke P, Scherer SW, Zhuang Z, Lubensky I, Dean M, Allikmets R, Chidambaram A, Bergerheim UR, Feltis JT, Casadevall C, Zamarron A, Bernues M, Richard S, Lips CJ, Walther MM, Tsui LC, Geil L, Orcutt ML, Stackhouse T, Zbar B, et al. 1997. Germline and somatic mutations in the tyrosine kinase domain of the MET proto-oncogene in papillary renal carcinomas. Nat Genet 16:68-73

Schmidt L, Junker K, Weirich G, Glenn G, Choyke P, Lubensky I, Zhuang Z, Jeffers M, Vande Woude G, Neumann H, Walther M, Linehan WM, Zbar B. 1998. Two North American families with hereditary papillary renal carcinoma and identical novel mutations in the MET proto-oncogene. Cancer Res 58:1719-1722.

Sharp PA. 1981. Speculations on RNA splicing. Cell 23:643-646.

Waltz SE, Toms CL, McDowell SA, Clay LA, Muraoka RS, Air EL, Sun WY, Thomas MB, Degen SJ. 1998. Characterization of the mouse RON/Stk receptor tyrosine kinase gene. Oncogene 16:2742 . 
Wang M-H, Ronsin C, Gesnel MC, Coupey L, Skeel A, Leonard EJ, Breathnach R. 1994. Identification of the RON gene product as the receptor for the human macrophage stimulating protein. Science 266:117-120.

Wei MH, Latif F, Bader S, Kashuba V, Chen JY, Duh FM, Sekido Y, Lee CC, Geil L, Kuzmin I, Zabarovsky E, Klein G, Zbar B, Minna JD, Lerman MI. 1996. Construction of a 600-kilobase cosmid clone contig and generation of a transcriptional map surrounding the lung cancer tumor suppressor gene (TSG) locus on human chromosome 3p21.3: progress toward the isolation of a lung cancer TSG. Cancer Res 56:14871492.

Zbar B, Lerman M. 1998. Inherited carcinomas of the kidney. Adv Cancer Res 75:163-201.

Zbar B, Brauch H, Talmadge C, Linehan M. 1987. Loss of alleles of loci on the short arm of chromosome 3 in renal cell carcinoma. Nature 327:721-724.

Zhen Z, Giordano S, Longati P, Medico E, Campiglio M, Comoglio PM. 1994. Structural and functional domains critical for constitutive activation of the HGF-receptor (MET). Oncogene 9:1691-1697. 